\title{
Reaction to Prof. Mercer's paper: Education and the social brain: linking language, thinking, teaching and learning
}

Jean-Charles Chabanne

\section{(2) OpenEdition \\ Journals}

Electronic version

URL: http://journals.openedition.org/educationdidactique/2524

DOI: $10.4000 /$ educationdidactique.2524

ISSN: 2111-4838

Publisher

Presses universitaires de Rennes

\section{Printed version}

Date of publication: 8 July 2016

Number of pages: $35-47$

ISBN: 9782753551787

ISSN: 1956-3485

\section{Electronic reference}

Jean-Charles Chabanne, «Reaction to Prof. Mercer's paper: Education and the social brain: linking language, thinking, teaching and learning », Éducation et didactique [Online], 10-2 | 2016, Online since 08 July 2018, connection on 01 May 2019. URL : http://journals.openedition.org/ educationdidactique/2524; DOI : 10.4000/educationdidactique.2524 


\section{SOCIAL BRAIN OR INSTITUTIONS, CULTURAL TOOLS AND SOCIAL PRACTICES? \\ HOW TO EXPLAIN SCHOOL PROCESSES AND INEQUALITIES? COMMENTS ON NEIL MERCER'S PAPER}


Jean-Yves Rochex

\section{INTRODUCTION}

I would try here to comment and discuss Neil Mercer's very interesting paper (and two other ones he published before: Mercer, 2013; Mercer $\&$ Howe, 2012) from my point of view and my research topics which aim to describe and to explain the social and school processses of construction of school inequalities by crossing the contribution and the questions of different research fields: cultural psychology (especially Vygotskian theory), didactics and sociology. Of course, I agree with the main theoretical propositions which are the core of Neil Mercer's argument (especially the social nature of human cognition and its consequences for education and teaching-learning processes), but I would try to discuss the "social brain hypothesis," to read Vygotski's works and to distinguish and to develop the different meanings ot the word social in our research approaches and conceptual frames, in some different ways than Neil Mercer does.

\section{IS "SOCIAL BRAIN" A USEFUL CONCEPT OR METAPHOR?}

Of course, the progress of knowledge about the brain's structures and functions is nowadays very fast and impressive, and psychology and educational sciences must pay special attention about what Dunbar (1998) and other researchers named "social brain hypothesis" or "the brain's prosociality." This hypothesis argues that "human brain is designed to enable people to adjust sensitively to one other's perspectives and emotions, so as to enable cooperative activity from which a whole community can benefit" (Wolpert \& Frith, 2004, quoted in Mercer, 2013), and that this design was a decisive advantage in the evolutionary struggle for survival and expansion of human species. Neil Mercer emphasises the interest but also the limits and the risks of such a concept or hypothesis when he remarks that "theory of mind," and even "mirror responses" are not hardwired in human (or primate) brain but are changed by experience and developed through practice and guidance, and especially when he writes:

"The social brain hypothesis entails a significantly different conception of human intelligence from that which has usually been adopted in mainstream psychology. However, there is a danger that this perspective merely employs the concept of the social brain to generate a new style of individualistic explanation for how people are able to negotiate the social world, and why some of our individual ancestors managed to "survive" in that world better than others. That is, it is still associated with an inherently individualistic conception of human cognition. Thus evolutionary psychologists tend to argue for the value of intermental sensitivities for promoting individual success in competition and combat (e.g. Harcourt, 1989, cited in Dunbar)" (Mercer, this issue).

So I agree absolutely with Mercer when he argues, about social brain hypothesis, that "its current conceptualization is too narrow and individualistic" (Mercer, 2013). But I'm not sure that, as he writes, "we need to expand the concept of the social brain" (this issue), or that "(this) concept should be redefined to take account of the distinctive human capacity for thinking collectively" (Mercer, 2013), to take account of "the ability to more than just interact, but rather to "interthink" as "a key characteristic of the social brain" (this issue), and that "Vygotskian socio-cultural theory offers a framework for this reconceptualization" (Mercer, 2013). In other words, I doubt that "social brain" is a real concept; I think it's rather a metaphor. And I'm afraid using this metaphor involves more inconveniences than advantages.

I think psychologists and education researchers need to be very cautious when they use such a metaphor both because (in epistemological register) of the risk of reductionism which believe it's possible to see or to find the secrets and the explication of our social behaviours in our brain's structure and modes of functioning, and because of the very strong claim by many neuroscientists to be able - now or, if not, tomorrow - to predict or to rule all psychological or educational processes, even to prescribe to teachers how to teach and how to deal, no more with children but with their brain. A caricatural exemple of such a claim was very recently published on the first page of Science and Medicine supplement of the French famoust daily, Le Monde: Laurent Alexandre, a surgeon, who presents himself as a neuro-revolutionary, argued that, in 2050, school will no more deal with knowledge but with brains, neuroscientists must help teachers to became neuro-growers, and teaching must be 
personnalized according to neurobiological and cognitive caracteristics of each pupil; so he concluded that it would be necessary henceforth to call on a neuroscientist to be the Minister of education (Alexandre, 2015).

Of course, most of arguments about the social brain are far from such a caricature, but most of their authors do share the belief that the concept of social brain is useful to understand how we think or we feel. I think there is in the social brain hypothesis a danger to confuse two different topics: the brain's structure and modes of functioning as condition of possibility for our social (and cultural) behaviours, and as an explication for these behaviours. Of course the first topic is undeniable and to increase the knowledge we have of brain's structure and functioning is very important. But could we think (or hope) it will be possible (both from empirical and theoretical point of view) to report what we think or feel, and the way we do it, to neurobiological structures and mecanisms, even if we consider that these structures and mecanisms are numerous, diverse and complex? What is the sense of the word social in the utterance social brain? And, if we consider that neurosciences could be social, couldn't we be dubious about the status of a social concept or a social register which could be supposed to receive an ultimate explication in non-social but biological terms? ${ }^{1}$

So, what is the main characteristic which could explain the huge gap between primate and humankind? Is it only an additional degree of brain's complexity, due to evolution? Or is it, according to the French social anthropologist André LeroiGourhan, the fact that "from homo sapiens onwards, the construction of a social memory equipment prevails over all human evolution questions. [...] All the human evolution converges to put out of human individual what, in the other animal species, responds to specific adaptation," so that "social memory gradually substitutes for instinct biological devices" 2 (Leroi-Gourhan, 1965). Then, I don't think that "the essentially social quality of human cognition" could be represented by the concept of social brain, but rather by the switch from biological evolution to social history and cultural devices accumulation and transmission. If human cognition and sensibility are biologically based, they are not biologically shaped and explainable; their origins and the processes by which they take forms and contents cannot be found in the brain, nor in the individual, but in institutions and cultural artefacts and practices which organize social life for everybody. ${ }^{3}$

Although he was very interested in the knowledge of brain, Vygotski criticised strongly the solipsism of biological or individualistic conceptions of human cognition and its development: "To discover the source of thought, we need to go out of the organism's boundaries, and to go not in the inner sphere of mind, but in the objective forms of social life. The origins of human consciousness and liberty must be inquired in social history of mankind. To find the soul, we need to lose it"4 (Vygotski, quoted in Luria, 1966). ${ }^{5}$ Then, the motor of human development, of human cognition and sensiblity is not in the brain or in the biological equipment of each individual, but in the discrepancy and the contradiction (the drama in Politzer's words) between the limits and the incompletion of individuals and the successive achievements of institutions ${ }^{6}$ and works, ${ }^{7}$ "between the developed cultural forms of thinking, acting and feeling in which children are involved and the primitive forms which characterize their own behavior"8 (Vygotski, 1931/2014).

\section{HOW TO THINK THE RESEARCH ON CLASSROOM PARADOX?}

Maybe Neil Mercer will not disagree with all I wrote above, and the questions at stake could be more a problem of formulation or of emphasis put on some aspects rather than on some other ones. For my part, although I'm dubious about this concept or metaphor, I do agree with the main theses that Mercer draws from his discussion of the social brain hypothesis, namely the paramount importance of joint intellectual ${ }^{9}$ activity and collaboration for human development and for the human "ability to more than just interact, but rather to interthink," the crucial and specific functions of language as an institution and as practices and genres both to collective thinking and joint activity and to move from interpsychological thinking and relationship to intrapsychological ones, from other-regulation to self-regulation. Mercer and Howe' remarks that working in groups is not sufficient to work as a group are very useful to prevent us from pedagogical naivety and from a lot of current commonplaces which tend to persuade us that pupils could learn essentially by interaction and discussion between themselves 
Jean-Yves Rochex

regardless of teacher's activity and intervention. And their descriptions and analyses of many examples of implementation of transactive dialogue, reasoned discussion, exploratory or accountable talk are very suggestive both for teachers and for educational researchers; as very convincing is their proposition "to give the critical examination of classsroom dialogue higher priority in teachers' initial training and professional development" (Mercer \& Howe, 2012). But Mercer and Howe draw our attention on the fact that "there can be confusion and uncertainty over what precisely joint activity should mean," and "over what precisely classroom dialogue should mean or must be" (our addition). Of course, joint activity and classroom dialogue depend on the nature of task, knowledge or practice involved and on the grade of pupils; they vary and must be specifically described and analysed - by researchers - and organized - by teachers - regarding these aims and context.

Such a work is difficult and, although they review different research evidence which show that the quality of dialogue and interaction - between pupils and between teacher and pupils - in classroom improve collaborative learning and the quality of educational outcomes, Mercer and Howes note nevertheless that "one of the first messages to emerge from work surveying classroom activity is that truly collaborative activity rarely happens" (Mercer \& Howe, 2012) or that "research shows that Exploratory Talk is quite rare in classroom, in comparison with less analytic and less collaborative types of interaction" (Mercer, this issue). Then, we need to think and analyse the reasons for such findings, both in and out of classroom, and I argue we need, to do that, to expand the uses we do of vygotskian theory beyond the classroom boundaries, towards cultural artefacts and tools and towards social determination of classroom processes and interactions.

Post-piagetian researchers have shown more than thirty years ago that sociocognitive conflict may or not be beneficial to improve children' or students' thinking and problem solving. ${ }^{10}$ The conditions of such an improvement are that sociocognitive conflict could be cognitively explicited, discussed and solved and, to allow this regulation, that otherregulation could be ruled on cognitive or knowledge register (which is, on a large part, impersonnal register, ruled by norms which are not dependent to individuals and their ordinary interactions, but to social external institutions and cultural tools) rather than on social one, ruled by social, gender or school status ("I'm right because I'm a good pupil, or because mathematics are not woman's element") or by children' self-esteem ("I don't know, it's too hard for me. I have never done this before. So you could do it better than me"). Mercer's papers argue judiciously that these conditions apply to classroom talk or dialogue, and show that they cannot be taken for granted:

"Research on classroom-based group work embodies a paradox: it has shown the value of collaborative learning, but it has also shown that much of the group activity which goes on in classroom has little educational value. [...] Children may not have many opportunities to learn how to conduct reasoned discussions in their out-of-school lives, or may not realize that they should engage in them when given collaborative tasks in the classroom. If their teachers do not raise their awareness of how they might talk and work together, or provide them with models and guidance, they are unlikely to develop the relevant skills for collective thinking and apply them appropriately. It is not so surprising, then, that in peer group discussion, the talk is often off-topic, unproductively disputational and inequitable" (Mercer, 2013).

So, to be relevant to knowledge acquisition and to be beneficial to the progress of pupils, peer group work and discussion, classroom talk and dialogue, must be not only teacher-led, but also teacher-ruled and granted regarding not only task or problem solving but also knowledge and thinking stakes which are theoretically involved in task or problem solving. The challenge needs strong professional competencies and a constant and acute vigilance regarding the nature of tasks and of pupils' activity and exchanges, the vocabulary and genres of discourse specific to subjects and their approaches. It needs also that teachers could use ordinary these competencies and vigilance whatever the social and institutional context of their school, and whatever their pupils' social background or gender. Sociological researches about classroom activities and discourses show that it happens rarely, and that the multimodality of classroom processes, which involve simultaneously gestures, material or semiotic artefacts and devices, language practices and physical settings, could both shape learning processes for 
some pupils but misunderstandings or wrong ways for other ones, sometimes during what is apparently the same classroom setting and collective activity.

\section{BERNSTEIN AND VYGOTSKI: TO GIVE TO VYGOTSKIAN APPROACH ITS FULL SOCIAL DIMENSION}

At this point, I think it's necessary to complete vygotskian approach by a sociological one. Or, more exactly to develop vygotskian theory to give to this approach and theoretical point of view, its full sociological dimension. And I will argue here that the sociological works and concepts proposed by Basil Bernstein, who has read very carefully Vygotski's works, could be very precious to do that. ${ }^{11}$ Bernstein frequently refers to Vygotsky's work as one of the major references upon which he founded his own thought, particularly by contrast with Piaget's theory (which he describes as "abstract structuralism") and with all the theories that tend to converge towards the "idealism of competence" achieved "at the price of abstracting the individual from the analysis of distributions of power and principles of control which selectively specialise modes of acquisition and realisations" (Bernstein, 2000, p. 43). The major Vygotskian thesis of a social genesis of thought and consciousness through activities carried out in common with others certainly reflects his own theoretical and empirical interests. Yet, for Bernstein, the reference to Vygotsky's theory remains critical. According to him, the Russian psychologist was unable to infer all of the sociological implications of his thesis because of his overly restrictive conception of development, which exposed him to the risk of linguistic or instrumental determinism:

\footnotetext{
"Vygotsky appeared to have a restricted view of development, essentially cognitive, and a practice which appears to privilege the acquisition of the 'tool' rather than the social context of acquisition [...]. The metaphor of 'tool' draws attention to a device, an empowering device, but there are some reasons to consider that the tool with its internal specialized structure is abstracted from its social construction" (Bernstein, 1994, p. 17).
}

The issue here is not merely the need to take account, between History and the development of individuals, of the specific histories and different or unequal development of the various social formations, as Sylvia Scribner has already insisted in a critical discussion of Vygotskian theory (Scribner, 1985), but also the need to take account of the inherent heterogeneity, conflictuality and inequalities which characterise every social formation, as Ruqaiya Hasan insists in writing that "where Vygotsky appears to see homogeneity, Bernstein, from the very beginning, sees heterogeneity" (Hasan, 2004, p. 36). Hasan underlines the complementary nature of Vygotsky's and Bernstein's approaches, but also emphasizes what she sees as the more heuristic and more elaborated character of Bernstein's study of the relations between family socialisation and school socialisation and between "local" and "official" pedagogical modalities, and the possibility of giving them their full sociological dimension:

\footnotetext{
"The school is where the business of learning is 'institutionalized' but, as Vygotsky pointed out, 'any learning the child encounters in school has a previous history' (Vygotsky, Mind in Society, p. 84). Bernstein's message on this issue was more elaborated: he tried to show us what previous histories of discursive participation different groups of children bring to the school and how this history might impinge on learning in school given the nature of the official pedagogic systems" (Hasan, 2002, p. 547).
}

Bernstein's and Hasan's assumptions invite us to study carefully how these previous histories of discursive activity, but also the classroom practices and pedagogic discourses and the way teachers cope with different pupils or different type of pupils, could impige on learning, to improve or to impede it, and consequently could contribute to social school inequalities production. This topic is the central one in our researches ${ }^{12}$ and I would try to summarize our main results about it. ${ }^{13}$ First findings are that pupils who are the less acquainted with school habits and requisites, because of their family socialisation, have a lot of difficulties in coping with classroom specific multimodality and in relating judiciously tasks, material artefacts, language practices and discourses, and knowledge or conceptual contents. These pupils, who are more often than not pupils from desadvantaged social background, are often mistaken about the right way to interpret school situations, tasks and requisites and about the sort of dialogue or language practices needed to learn and to 
Jean-Yves Rochex

elaborate their thought moreover. So one of the most recurrent misunderstundings we observe is the one which leads many pupils - lower classes pupils more than middle classes ones, boys more than girls - to consider learning as a succession of fragmentary tasks or exercises, of concrete procedures or routines to carry out, without being able to relate these ones with the general principles of specific knowledge fields, even in inchoate way. These pupils do not perceive the knowledge and learning questions and stakes, beyond the contexts, the tasks, the rituals or the behaviour rules of classroom. So they focused on performance, on answers they think teacher expects from them, more than on the cognitive treatment of the tasks. As Piaget would say, ${ }^{14}$ they attempt to succeed more than to understand what is necessary to succeed. Therefore they cannot recognize (identify and consider as worthwhile) any specificity or any unity to academic subjects like mathematics or grammar, and each task is perpetually new, each task erases the former one. When interviewed about their school activities or about what occurs in classroom, they can tell factual events and describe what they did, they can say what about they spoke, but they seldom consider what they were supposed to learn or how to learn. These pupils can seldom control by themselves their cognitive functionning and depend very often on an external control or judgement. More generally, they are very dependent on adult's activity and person and they often confuse the level of the rules needed to live together in classroom (the regulative or horizontal discourse, in bernsteinian words) or the register of ordinary experience or exchanges with the level of the rules and the specific point of view needed to learn a specific subject (the instructional or vertical discourse in bernsteinian words). Then, they are pupils whose talk and dialogue practices are more often off-topic, unproductively disputational and unefficient to learn and think otherwise than they did before dialogue or task carrying out.

Then it's clear that all pupils - and pupils from different social and cultural backgrounds - are not equally prepared to interpret and decipher school habits and requisites. But the problem of school inequalities does not limit to that. The problem lies also in the fact that teachers are unequally conscious of this question and that their ways to cope with what they perceive about their pupils' characteristics and difficulties may confirm or increase these difficulties and school inequalities. Let us give some examples of these processes, all quoted from our researches (Rochex \& Crinon, 2011). In a period where prevails a constructivist vulgate which prescribes that pupils must be "active," sometimes regardless the cognitive nature of their activity, the priviledge given to activity means too often that teachers focus on tasks and problem solving, on pupils right or wrong answers or realization, to the detriment of concepts, of knowledge stakes beyond the tasks. Then these stakes could remain implicit or opaque for pupils who remain alone, without guidance or sufficient one, to relate together differents tasks or these tasks to decontextualised knowledge contents and ways of thinking which allow them to be prepared to future more difficult tasks and situations.

Many efforts are done by teachers to propose attractive, motivating or "familiar" situations and tasks to their pupils, especially when they belong to desadvantaged social backgrounds. But, even if these efforts are fruitful to engage pupils in tasks, they are most of times unsufficient to allow or to help them to recognise what they are supposed to learn in carrying tasks out, and teachers are not always conscious of the necessity to pay as much attention and efforts to this question than to the first one. The worst is that, sometimes, the efforts to make tasks or situations attractive or genuine (that means very often not articial and not academic) could blur the nature and the aims of the task. For instance, we have observed in a primary school a session when the teacher aimed to make her pupils work on mathematics, especially on percentages. This session took place just one day after a national polling. So that the teacher thought it could be a good idea to propose to her pupils to make computations - to transform the numbers of different votes in percents and return - with this polling's results. Of course, as a middle class member, she knew very well what is a polling and how to read its results. But pupils did not, because their parents, as working class or unemployed people, are often abstaining. Then the session, which was designed as a mathematics one, shifted very quickly to civic instruction lesson, and the initial aims disappeared soon behind civic informations (or, for a part, moral and political reproaches adressed to parents via their children) and pupils' "political opinions" confrontation, without any debate being possible. This kind of blurring of the nature and the aims of activity - whose we could give many other 
examples - is linked with and strenghtened by the focus put on tasks and situations rather than on their learning stakes, on pupils' busying rather than on teaching.

It goes very often together with another blurring regarding language practices and genres of discourse. Our findings show that teachers could make narrowed uses of language, especially towards low achievers or working class pupils. In teacher pedagogic discourse (or in interactions with pupils or with some of them), these teachers do not use or use rarely the "words of knowledge," the formulations or the terms specific to subject matters, or the meta-linguistic interventions, re-formulations, corrections or resumptions which could allow pupils to generalize, to decontextualize or to depersonalize such answer or such way of doing. So they do not allow pupils to embed and to root what they work, the task or the problem they solve, the answer they give, in a conceptual coherence and continuity. Verbs and nouns which name intellectual operations or relevant properties are rarely used for the benefit of usual words and ordinary experience language. The teacher says for instance "look if it's the same" rather than "compare"; he/she does not use the words angles, right angles or sides, but peaks, corners and edges, and then narrows the understanding of the components and properties of geometric figures to the perception or - at best - to the description of the wooden pieces of puzzle he/she used during the lesson. In the same way, norms and requirements to judge the relevance of an answer or a way of doing could be formulated mainly regarding formal or behavioral criteria or regarding agreement or disagreement with peers, regardless of explicit and developed references to specific criteria of reasoning, argumentation or "proofs debate" in mathématics, grammar, technology or history.

We are far from reasoned dialogue or exploratory talk described and defended by Mercer. As I said already, our findings allow us to think, like other researchers, ${ }^{15}$ that these practices, these narrowed pedagogy and discourses are more frequent when teachers adressed to lower class or low achievers pupils. And we could observe, in the same classrooms, what we called, after SchubauerLeoni (1988), differential didactic contracts, that is recurrent interaction formats between teacher and pupils, which are different from one kind of pupils to another, and which narrow roughly intellectual work proposed to lower calls or low achievers pupils and possible for them. The differentiation of the tasks proposed to different kind of pupils, of the framing of their activity, of the discourse and interaction adressed to them, leads thus to differentiate the universes of knowledge proposed to different kinds of pupils and those they can use of, and then to create not only different but unequal ways of working, possibilities of learning and cognitive benefits.

\section{WHAT DO WE MEAN WHEN WE SAY SOCIAL?}

These findings must led us to consider that pupils' or teachers' practices and discourses are not only shaped by what occurs in classroom space and time, but are also shaped by their out-of-school experience and social relationship, in other words (Bourdieu's ones) by their social habitus. Then I think we must ask what we mean when we say that classroom situations and practices are social ones, or when we speak about the social nature of human cognition. In order to understand, and eventually to transform, classroom situations and practices (like other ones), I argue it's necessary to link the three different meanings of the word social. First, this word refers to interactions between different persons, in situation time and space, as in most researches about socio-cognitive conflict or about pedagogical processes. Second, this word refers to the sociohistorical framing of school processes, which are both embedded or rooted in school and language as institutions ${ }^{16}$ and in subjects as socio-historical constructs but also as epistemological or cultural specific registers and communities of practices and of discourses. This second meaning refers to what Vygostki - who could not be considered as an interactionist psychologist like did a lot of his followers or commentators - called cultural and psychological tools, to the knowledge and thinking contents and tools which constitute mankind's and societies' external social memory and mental equipment; didacticians and historians of school are specifically interested by it. These two meanings and registers of study are foregrounded in Vygotski' works. The third meaning, crucial for sociologists, refers to the fact that each society is structured by social relations and conflicts and devided between different social milieus which differ more or less regarding ways of thinking and social habitus. As Bernstein (1993) remarked, it remains vague in 
Jean-Yves Rochex

Vygotski's works - likely because of the teologic conception of history of the Russian revolution time - and also in Mercer's paper. Nevertheless I think it's as important as the two other ones to study and to understand what happens in classroom and to consider what happens in classroom is not totally build and structured in classroom space and time. It is clear for me that the social brain concept or hypothesis is only able to account of the condition of possibilty of the first meaning of the word social but is unable to account of the two other ones.

\section{NOTES}

1. Regarding these questions, see Ambroise et Chauviré, 2013.

2. "À partir de l'homo sapiens, la constitution d'un appareillage de la mémoire sociale domine tous les problèmes de l'évolution humaine. [...] Toute l'évolution humaine concourt à placer en dehors de l'homme ce qui, dans le reste du monde animal, répond à l'adaptation spécifique", et donc à "la substitution progressive de la mémoire sociale au dispositif biologique de l'instinct" (Leroi-Gourhan, 1965, pp. 24 and 34).

3. Regarding these questions, see Bruner, 1990 or Tomasello, 1999.

4. "Pour découvrir les sources de la pensée, il faut sortir des limites de l'organisme, et ce non dans la sphère intime de l'esprit mais dans les formes objectives de la vie sociale. Il faut rechercher les sources de la conscience et de la liberté humaines dans l'histoire sociale de l'humanité. Pour trouver l'âme, il faut la perdre."

5. This quotation echoes the famous Marx's sixth these on Feuerbach: "The human essence is not an abstraction inherent in each single individual. In its reality it is the ensemble of social relations" ("L'essence humaine n'est pas une abstraction inhérente à l'individu pris à part. Dans sa réalité, c'est l'ensemble des rapports sociaux").

6. See Douglas, 1986/1999.

7. On this point, see Meyerson, 1948/1995.

8. La contradiction "entre les formes culturelles évoluées du comportement avec lesquelles l'enfant entre en contact et les formes primitives qui caractérisent son propre comportement."

9. Intellectual activity must be understood here in a large meaning, including material, technical, semiotic, linguistic and intellectual practices.

10. See, for the first works about this topic PerretClermont, 1979; Doise and Mugny, 1981.

11. The following development is quoted from Rochex, 2008/2011.

12. When I write "our researches," I mean Escol laboratory's and Reseida network's collaborative researches.

13. For more developments, see Rochex and Crinon, 2011. 14. See Piaget, 1974.

15. See for instance Crocco and Costigan, 2007 or Kherroubi and Rochex, 2004.

16. Remember Wittgenstein's warning when he argued that we don't agree with other people about language but above all in language. 


\section{REFERENCES}

Alexandre, L. (2015). Lécole face à l'intelligence artificielle. Le Monde, supplément Science et médecine, 8 avril 2015.

Ambroise, B., \& Chauviré, C. (Eds.) (2013). Le mental et le social, Raisons pratiques, 23. Paris: EHESS.

Bernstein, B. (1993). Forward. In H. Daniels (Ed.), Charting the Agenda. Educational activity after Vygotsky. London: Routledge.

Bernstein, B. (2000). Pedagogy, Symbolic Control and Identity: Theory, Research, Critique (Rev. ed.). Lanham, Rowman \& Littefield Publishers.

Bruner, J. (1991). Car la culture donne forme à l'esprit. De la révolution cognitive à la psychologie culturelle (French trans., Rev. ed.). Paris: Eshel.

Crocco, M. S., \& Costigan, A. T. (2007). The Narrowing of Curriculum and Pedagogy in the Age of Accountability Urban Educators Speak Out. Urban Education, 42(6), 512-535.

Doise, W., \& Mugny, G. (1981). Le développement social de l'intelligence. Paris: InterÉditions.

Douglas, M. (1999). Comment pensent les institutions (French trans.). Paris: La Découverte.

Dunbar, R. (1998). The social brain hypothesis. Evolutionary Anthropology, 6, 178-189.

Hasan, R. (2002). Ways of Meaning, Ways of Learning: Code as an Explanatory Concept. British Journal of Sociology of Education, 23(4), 537-548.

Hasan, R. (2004). The concept of semiotic mediation: perspectives from Bernstein's sociology. In J. Muller, B. Davies \& A. Morais (Eds.), Reading Bernstein, Researching Bernstein (pp. 30-43). London: Routledge Falmer.

Kherroubi, M., \& Rochex, J.-Y. (2004). Note de synthèse. La recherche en éducation et les ZEP en France. 2. Apprentissages et exercice professionnel en ZEP : résultats, analyses, interprétations. Revue française de pédagogie, 147, 115-190.

Luria, A. (1966). Vygotski et les fonctions psychiques. Recherches internationales à la lumière du marxisme, 51, 86-97.
Mercer, N. (2015). Education and the social brain: linking language, thinking, teaching and learning. Éducation $\mathcal{E}$ Didactique, 10(2).

Mercer, N. (2013). The social brain, language and goaldirected collective thinking: a social conception of cognition and its implication for understanding how we think, teach and learn. Educational Psychologist, 48(3), 1-21.

Mercer, N., \& Howe, C. (2012). Explaining the dialogic processes of teaching and learning: the value and potential of sociocultural theory. Learning, Culture and Social Interaction, 1, 12-21.

Meyerson, I. (1995). Les fonctions psychologiques et les œuvres (Rev. ed.). Paris: Albin Michel.

Piaget, J. (1974). Réussir et comprendre. Paris: Presses universitaires de France.

Perret-Clermont, N. (1979). La construction de l'intelligence dans l'interaction sociale. Bern: Peter Lang.

Rochex J.-Y. (2008). L'œuvre de Bernstein: une sociologie non déterministe, parce que non sociologiste. In D. Frandji \& P. Vitale (Eds.), Actualité de Basil Bernstein. Savoir, pédagogie et société (p. 101-118). Rennes: Presses universitaires de Rennes.

Rochex, J.-Y., \& Crinon, J. (Eds.) (2011). La construction des inégalités scolaires. Au cour des pratiques et des dispositifs d'enseignement. Rennes: Presses universitaires de Rennes.

Schubauer-Leoni, M.-L. (1988). Le contrat didactique dans une approche psycho-sociale des situations d'enseignement, Communication au colloque « Le contrat didactique, différentes approches », Marseille, mars 1987. Interactions didactiques, 8, 63-75.

Tomasello, M. (2004). Aux origines de la cognition humaine (French trans.). Paris: Retz.

Vygotski, L. S. (1931/2014). Histoire du développement des fonctions psychiques supérieures (French trans.). Paris: La Dispute. 